\title{
Everynight Life
}

A book in the series

Latin America Otherwise: Languages, Empires, Nations

Series editors: Walter D. Mignolo, Duke University

Irene Silverblatt, Duke University

Sonia Saldívar-Hull, University of California at Los Angeles 


\section{Everynight Life}

\section{Culture and Dance in Latin/o America}

Celeste Fraser Delgado and José Esteban Muñoz, editors

Duke University Press Durham and London

1997 
(C) 1997 Duke University Press

All rights reserved

Printed in the United States of America on acid-free paper $\infty$

Typeset in Palatino with Gill Sans display by Keystone Typesetting, Inc.

Library of Congress Cataloging-in-Publication Data

Everynight life : culture and dance in Latin / o America / edited by

Celeste Fraser Delgado and José Esteban Muñoz.

p. cm. - (Latin America otherwise)

Includes bibliographical references and index.

ISBN 0-8223-1926-8 (cloth : alk. paper). - ISBN 0-8223-1919-5

(pbk. : alk. paper)

1. Dance-Latin America-History. 2. Dance-Latin America-

Sociological aspects. 3. Dance-Political aspects-Latin America.

I. Delgado, Celeste Fraser. II. Muñoz, José Esteban. III. Series.

GV1626.E84 1997

$792.8^{\prime} 098-\mathrm{dc} 20 \quad 96-43796 \quad$ CIP 


\section{Para Ramón Torres}

Seguimos trazando los pasos que tu bailaste en este mundo.

We are still tracing the steps you danced in this world. 
